\title{
Differences in Pituitary and Testicular Function between Diabetic Patients on Insulin and Oral Anti-Diabetic Agents
}

\author{
M. M. Shahwan ${ }^{1}$, G. S. Spathis ${ }^{1}$, D. E. Fry ${ }^{2}$, P. J. Wood ${ }^{3}$, and V. Marks ${ }^{3}$ \\ ${ }^{1}$ Department of Medicine, St. Helier Hospital, Carshalton, Surrey, ${ }^{2}$ Epsom Hospital Laboratories at West Park Hospital, Epsom, Surrey, \\ and ${ }^{3}$ Department of Clinical Biochemistry, University of Surrey, Guilford, Surrey, England
}

Summary. Pituitary responsiveness to thyrotrophin releasing hormone (TRH) and luteinizing hormone releasing hormone (LHRH) was studied in thirty one male diabetics, of whom sixteen were insulin-dependent and fifteen on oral antidiabetic agents. Ten age-matched controls were also studied. TRH and LHRH were simultaneously administered intravenously, each in a small dose of $10 \mu \mathrm{g}$ followed two hours later by $190 \mu \mathrm{g}$ and $90 \mu \mathrm{g}$ respectively. Basal hormone levels were measured in a further group of thirty six patients (twelve on insulin, twelve on oral agents and twelve on dietary restrictions alone).

Higher thyrotrophin (TSH) response was observed following the small dose of TRH in the patients treated with oral agents than in the control subjects. The response of prolactin was lower in patients treated with oral agents compared with those treated with insulin. There was no difference in plasma $T_{3}$ and $T_{4}$ levels in the patients treated with insulin or oral agents. Significantly higher basal growth hormone $(\mathrm{GH})$ levels were observed in the diabetics. The insulin-dependent group showed a more marked response of GH to TRH/LHRH. No response was observed in the controls. Plasma testosterone levels were significantly lower in the oral agent group $(13.8 \mathrm{nmol} / \mathrm{l})$ than in the insulin group $(19.4 \mathrm{nmol} / 1)$, patients on dietary restrictions $(18.4 \mathrm{nmol} / 1)$ and the control subjects $(19.0 \mathrm{nmol} / \mathrm{l})$. The LH response to the smaller dose of LHRH was impaired in patients on insulin and oral agents. There was a significant difference in FSH response between impotent and sexually normal patients.

Key words: Diabetes, pituitary function, testicular function, testosterone, oral anti-diabetic agents, growth hormone, impotence, gonadotrophins, prolactin, insulin, thyrotrophin.
Disturbance of fertility and sexual function has long been recognised in patients with diabetes mellitus [ 1 , 2]. Impotence in particular is a common complaint which in normal subjects is frequently psychogenic $[3,4]$ but in diabetes may also be due to autonomic neuropathy [5] or angiopathy [6]. Different workers have sought to implicate endocrine factors in its pathogenesis but without consistency. Normal serum testosterone levels have been frequently reported [5, 7] in impotent diabetic patients. Although Schoffling et al. [8] claimed successful restoration of potency with testosterone therapy, most reports describe it as ineffective $[4,5]$.

More recently there have been conflicting reports of pituitary gonadal function in diabetic patients. Normal [9] luteinising hormone (LH) and blunted $[10]$ follicular stimulating hormone (FSH) responses to luteinising hormone releasing hormone (LHRH) stimulation have been reported while blunted $\mathrm{LH}$, but normal FSH, responses were demonstrated by Wright et al. [11]. Other aspects of pituitary function have also been studied with the demonstration of raised plasma thyrotrophin (TSH) $[12,13]$ and growth hormone $(\mathrm{GH})$ levels $[14,15]$. In view of the scarcity of dynamic studies of pituitary function in diabetes generally and the conflicting results in the few published reports, it was decided to evaluate pituitary responsiveness to LHRH and to thyrotrophin releasing hormone (TRH) in more detail.

\section{Materials and Methods}

\section{Patients and Controls}

Sixty seven male patients were studied. Twenty eight were insulindependent, (Age $50.5 \pm 3.5$ years), twenty seven on oral antidiabetic agents (Age 53.6 \pm 2.4 years) and twelve on dietary control alone (Age 57.6 \pm 3.5 years). The patients were randomly selected from the diabetic clinic of St. Helier Hospital. The main 


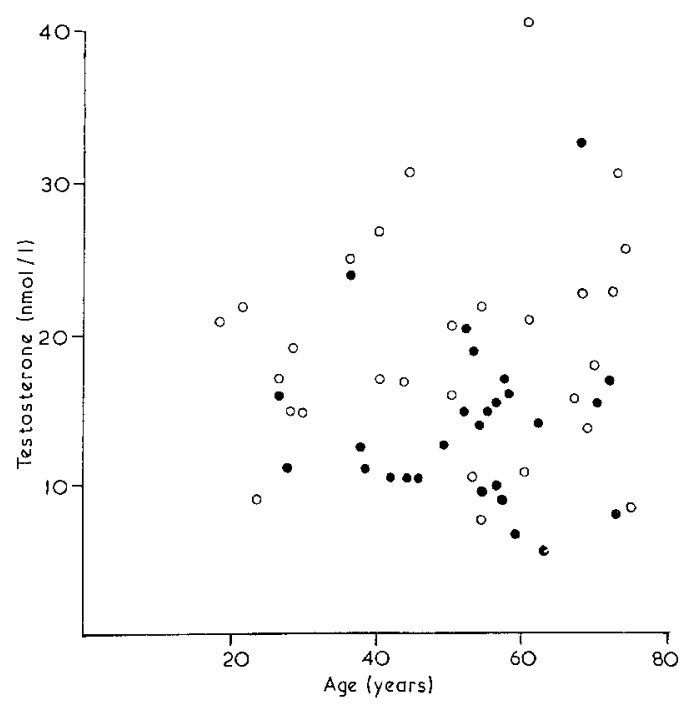

Fig. 1. Scatter diagram showing the relationship between age and plasma testosterone level for the insulin $(O)$ and oral agent $(\bullet)$ treated patients

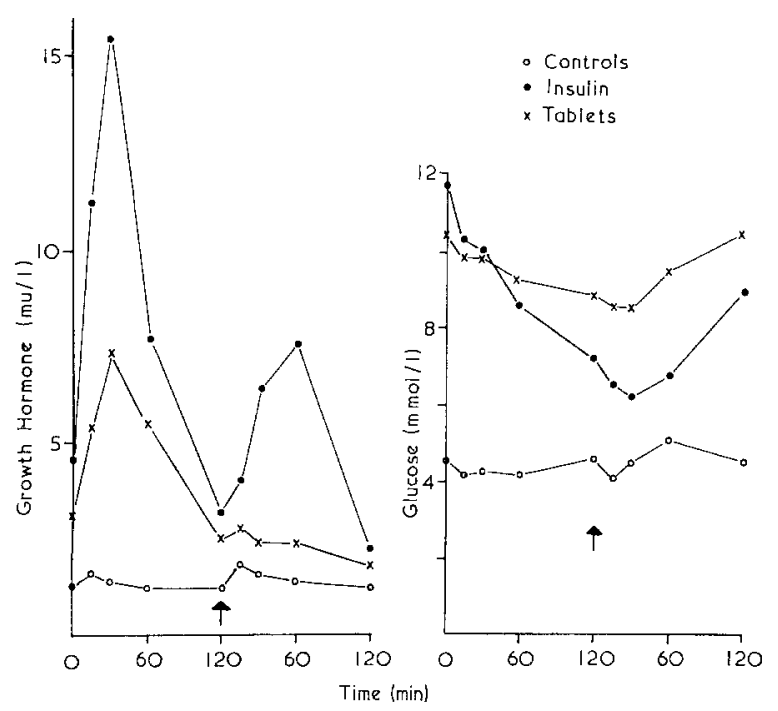

Fig. 2. Growth hormone and glucose response to IV TRH and LHRH in controls and diabetic patients. Zero time: $10 \mu \mathrm{g} \mathrm{TRH}$ and $10 \mu \mathrm{g}$ LHRH - 120 mins.: $190 \mu \mathrm{g}$ TRH and $90 \mu \mathrm{g}$ LHRH

oral anti-diabetic agent used was chlorpropamide. None was on any hormonal therapy other than insulin, nor any other treatment known to affect the blood levels of hormones or the mechanisms regulating their production or release. No patients had any known condition other than diabetes or were receiving other drugs than for the treatment of diabetes. On questioning, six patients on insulin and five on oral agents admitted to impotence, with failure of erection. Informed consent was obtained from all patients after full explanation of the nature and purpose of this study. Ten apparently healthy men served as voluntary controls (Age $41.4 \pm 4.3$ years). They were not receiving any drugs and were age-matched with the patients. Some were members of the medical and nursing staff and others were patients attending the surgical out-patient clinic for minor surgical problems.

\section{Investigations}

A combined TRH/LHRH test was carried out on thirty one of the patients (sixteen on insulin (Age 47.0 \pm 4.7 years) and fifteen on oral agents (Age $51.7 \pm 2.8$ years)), and on all ten control subjects. The test was started about $09.30 \mathrm{~h}$. Patients had breakfast and their usual medication before reporting to the investigation unit. On arrival the patient was put to bed and an indwelling plastic cannula inserted into an antecubital vein and kept patent by a slow infusion of $0.154 \mathrm{~mol} / \mathrm{l}$ saline. Base-line blood samples were collected, 30 minutes apart. Ten $\mu \mathrm{g}$ of TRH and of LHRH were then given from separate syringes through the indwelling cannula, and blood samples collected after 15, 30, 60 and 120 minutes. Further larger doses of TRH $(190 \mu \mathrm{g})$ and LHRH $(90 \mu \mathrm{g})$ were given immediately after collection of the 120 minute sample and blood samples again collected over a two hour period. Subjects were allowed to sit up and take mid-morning coffee and lunch. As soon as blood samples were obtained, the plasma was separated and stored at $-20^{\circ} \mathrm{C}$. All samples were assayed for prolactin, TSH, $\mathrm{GH}, \mathrm{LH}$ and FSH. Base-line samples were also assayed for $\mathrm{T}_{4}, \mathrm{~T}_{3}$ and testosterone. Blood glucose was measured in all specimens.

In thirty six other patients (twelve on insulin, twelve on oral agents and twelve on dietary restriction) only basal hormone levels were measured.

\section{Assay Methods}

Polypeptide and thyroid hormones were measured by radioimmunoassay (RIA). TSH was measured as described by Wood et al. [16], prolactin by the method of Sinha et al. [17] as modified by us [18], GH by the Lepetit Human GH Kit using IRP 66/217 as standard, LH as described by Wilde et al. [19] using LH (MRC 68/ 40) as standard, FSH using non-LH cross-reacting antiserum and FSH (MRC 69/104) as standard, triiodothyronine $\left(\mathrm{T}_{3}\right)$ using an antiserum raised at the University of Surrey and thyroxine $\left(\mathrm{T}_{4}\right)$ using the Radiochemical Centre Kit. Testosterone was assayed by a non-chromatographic RIA using an antiserum raised at the University of Surrey and having minimal cross-reactivity with other steroid hormones and metabolites. Glucose was measured using glucose-oxidase. The percentage binding of testosterone in plasma was measured as described by Rosenfield [20].

Statistical Evaluation: All results were reported as the mean \pm standard error of the mean. The significance of differences between means was tested using the ' $t$ ' test. The response of TSH, prolactin, $\mathrm{LH}$ and FSH was measured as the sum of the differences from baseline at 15, 30, 60 and 120 minutes for each hormone at both dose levels of TRH/LHRH.

\section{Results}

\section{Baseline Plasma Hormone Concentrations (Table 1)}

Plasma testosterone was lower in the patients on oral agents compared with both the insulin-treated and diet-controlled patients $(\mathrm{P}<0.01$ and $<0.05$ respectively) who themselves had levels similar to the control group. No correlation was observed between plasma testosterone and age (Fig. 1). Plasma GH was slightly, but significantly raised $(\mathrm{P}<0.05$ to $<0.01)$ in the three groups of diabetic patients compared with the control subjects. There was no difference in plasma prolactin, TSH, $\mathrm{T}_{3}, \mathrm{LH}$ and FSH levels be- 
Table 1. Basal serum hormone levels

\begin{tabular}{|c|c|c|c|c|c|}
\hline & & $\begin{array}{l}\text { Controls } \\
(n=10)\end{array}$ & $\begin{array}{l}\text { Patients } \\
\text { on insulin } \\
(n=28)\end{array}$ & $\begin{array}{l}\text { Patients on } \\
\text { oral agents } \\
(\mathrm{n}=27)\end{array}$ & $\begin{array}{l}\text { Patients on } \\
\text { dietary control } \\
(\mathrm{n}=12)\end{array}$ \\
\hline Thyrotrophin ${ }^{\mathrm{a}}$ & $\mathrm{mu} / \mathrm{l}$ & $1.7 \pm 0.6$ & $1.5 \pm 0.3$ & $2.4 \pm 0.6$ & - \\
\hline Prolactin & $\mu \mathrm{g} / 1$ & $2.3 \pm 0.7$ & $3.5 \pm 0.4$ & $2.7 \pm 0.4$ & $2.7 \pm 0.3$ \\
\hline Thyroxine & $\mathrm{nmol} / \mathrm{l}$ & $107 \pm 7$ & $114 \pm 4$ & $110 \pm 6$ & $128 \pm 4^{b}$ \\
\hline Triiodothyronine & $\mathrm{nmol} / \mathrm{l}$ & $2.3 \pm 0.2$ & $2.1 \pm 0.1$ & $1.9 \pm 0.1$ & $1.9 \pm 0.1$ \\
\hline Growth hormone & $\mathrm{mu} / \mathrm{l}$ & $1.3 \pm 0.2$ & $4.3 \pm 0.9^{c}$ & $3.3 \pm 0.8^{\mathrm{b}}$ & $6.0 \pm 1.4^{\mathrm{c}}$ \\
\hline $\begin{array}{l}\text { Luteinizing } \\
\text { hormone }\end{array}$ & $\mathrm{u} / \mathrm{l}$ & $4.9 \pm 0.7$ & $6.4 \pm 0.6$ & $6.4 \pm 0.5$ & $6.7 \pm 0.7$ \\
\hline $\begin{array}{l}\text { Follicle } \\
\text { stimulating } \\
\text { hormone }\end{array}$ & $\mathrm{u} / \mathrm{l}$ & $2.6 \pm 0.6$ & $3.1 \pm 0.3$ & $3.9 \pm 0.5$ & $3.8 \pm 1.3$ \\
\hline Testosterone & $\mathrm{nmol} / \mathrm{l}$ & $19.0 \pm 2.0$ & $19.4 \pm 1.4$ & $13.8 \pm 1.1^{b}$ & $18.4 \pm 2.2$ \\
\hline $\begin{array}{l}\text { Testosterone } \\
\text { binding }\end{array}$ & $\%$ & & $\begin{array}{c}54.9 \pm 1.7 \\
(\mathrm{n}=11)\end{array}$ & $\begin{array}{c}49.9 \pm 1.9 \\
(\mathrm{n}=11)\end{array}$ & $\begin{array}{c}50.3 \pm 1.8 \\
(\mathrm{n}=10)\end{array}$ \\
\hline Glucose & $\mathrm{mmol} / 1$ & $4.6 \pm 0.4$ & $11.8 \pm 1.4$ & $10.5 \pm 0.9$ & \\
\hline
\end{tabular}

a This was measured only in controls and those patients receiving TRH

b $\mathrm{P}<0.05$ compared with controls

c $\quad \mathbf{P}<0.01$

Table 2. Sum of responses of TSH, Prolactin, LH and FSH to LHRH/TRH in diabetic patients and control subjects

\begin{tabular}{|c|c|c|c|c|c|c|}
\hline & $\begin{array}{l}\text { Control } \\
(\mathrm{n}=10)\end{array}$ & $\begin{array}{l}\text { Insulin } \\
(\mathrm{n}=16)\end{array}$ & $\begin{array}{l}\text { Oral agent } \\
(\mathrm{n}=15)\end{array}$ & $\begin{array}{l}\text { Control } \\
(\mathrm{n}=10)\end{array}$ & $\begin{array}{l}\text { Insulin } \\
(\mathrm{n}=16)\end{array}$ & $\begin{array}{l}\text { Oral agent } \\
(\mathrm{n}=15)\end{array}$ \\
\hline \multirow{6}{*}{$\begin{array}{l}\text { TSH mu/l } \\
\text { a) } \\
\text { b) } \\
\text { LH u/l } \\
\text { a) } \\
\text { b) }\end{array}$} & & & & Prolactin $\mu \mathrm{g} / 1$ & & \\
\hline & $6.1 \pm 2.0$ & $4.6 \pm 1.0$ & $11.4 \pm 2.3^{c}$ & $13.2 \pm 3.7$ & $8.2 \pm 3.0$ & $4.1 \pm 1.6^{\mathrm{a}}$ \\
\hline & $28.0 \pm 4.8$ & $24.5 \pm 2.6$ & $30.7 \pm 4.1$ & $24.0 \pm 6.0$ & $20.3 \pm 5.8$ & $19.4 \pm 2.0$ \\
\hline & $45.8 \pm 4.8$ & $28.1 \pm 2.8^{\mathrm{b}}$ & $26.4 \pm 3.3^{b}$ & $\begin{array}{l}\text { FSH u/l } \\
8.4 \pm 1.8\end{array}$ & $5.0 \pm 1.2$ & $8.4 \pm 1.4$ \\
\hline & $50.8 \pm 7.9$ & $38.4 \pm 4.3$ & $31.8 \pm 5.8$ & $12.6 \pm 2.8$ & $8.1 \pm 2.0$ & $14.9 \pm 2.8$ \\
\hline & $\begin{array}{l}\text { Non-impotent } \\
(\mathrm{n}=20)\end{array}$ & $\begin{array}{l}\text { Impotent } \\
(\mathrm{n}=11)\end{array}$ & & $\begin{array}{l}\text { Non-impotent } \\
(\mathrm{n}=20)\end{array}$ & $\begin{array}{l}\text { Impotent } \\
(\mathrm{n}=11)\end{array}$ & \\
\hline \multirow{3}{*}{$\begin{array}{l}\mathrm{LH} u / \mathbf{l} \\
\text { a) } \\
\text { b) }\end{array}$} & & & & FSH u/l & & \\
\hline & $30.7 \pm 3.1$ & $22.7 \pm 2.3$ & & $5.4 \pm 1.2$ & $8.4 \pm 1.8$ & \\
\hline & $37.5 \pm 5.0$ & $32.0 \pm 4.8$ & & $8.6 \pm 1.8$ & $16.6 \pm 3.7^{\mathrm{d}}$ & \\
\hline \multicolumn{3}{|c|}{ a) Administration of $10 \mu \mathrm{g} \mathrm{LHRH}$ and $10 \mu \mathrm{g} \mathrm{TRH}$} & \multicolumn{4}{|c|}{$\begin{array}{ll}\text { a } & \mathbf{P}<0.05 \text { compared with control subjects } \\
\text { b } & \mathrm{P}<0.01 \text { compared with control subjects }\end{array}$} \\
\hline \multicolumn{3}{|c|}{ b) Administration of $90 \mu \mathrm{g} \mathrm{LHRH}$ and $190 \mu \mathrm{g}$ TRH } & \multicolumn{4}{|c|}{$\begin{array}{ll}c & \mathrm{P}<0.01 \text { compared with insulin subjects } \\
\text { d } & \mathrm{P}<0.05 \text { compared with non-impotent patients }\end{array}$} \\
\hline
\end{tabular}

tween the three groups of diabetic patients, nor between them and the control subjects. The $\mathrm{T}_{4}$ levels in the patients on dietary control was significantly raised when compared with control subjects.

\section{Responses of TRH/LHRH at Low and Standard Dose Levels (Table 2)}

The TSH response to the low dose of TRH in the patients on oral agents was greater than that of the patients on insulin $(\mathrm{P}<0.01)$. In contrast, the prolactin response in the patients on oral agents under these conditions was less than that of the control sub- jects $(P<0.02)$. Both groups of patients had a lower LH response than the control subjects to the low dose of LHRH $(\mathrm{P}<0.01)$, but the FSH responses were not significantly different.

There was no $\mathrm{GH}$ response in control subjects (Fig. 2). The insulin treated patients had a rise at both dose levels. The peak value at the low dose was $15.5 \pm 4.0 \mathrm{mu} / 1$ and at the standard dose $7.6 \pm$ $1.8 \mathrm{mu} / \mathrm{l}$. Patients on oral agents had a rise only after the low dose with a peak value of $7.4 \pm 2.0 \mathrm{mu} / \mathrm{l}$. At no stage were the patients hypoglycaemic nor did the $\mathrm{GH}$ responses correlate with changes in blood glucose. 
Table 3. Serum testosterone levels in impotent and sexually normal diabetic patients and control subjects

\begin{tabular}{lll}
\hline & \multicolumn{2}{l}{ Testosterone $\mathrm{nmol} / 1$} \\
\cline { 2 - 3 } & $\begin{array}{l}\text { Patients on } \\
\text { insulin }\end{array}$ & $\begin{array}{c}\text { Patients on } \\
\text { oral agents }\end{array}$ \\
\hline $\begin{array}{l}\text { Sexually normal diabetics } \\
(\mathrm{n}=20)\end{array}$ & $\begin{array}{l}19.6 \pm 3.0 \\
(\mathrm{n}=10)\end{array}$ & $\begin{array}{l}11.6 \pm 1.8 \\
(\mathrm{n}=10)\end{array}$ \\
$\begin{array}{l}\text { Impotent diabetics } \\
(\mathrm{n}=11)\end{array}$ & $\begin{array}{l}18.0 \pm 3.5 \\
(\mathrm{n}=6)\end{array}$ & $\begin{array}{l}14.5 \pm 1.6 \\
(\mathrm{n}=6)\end{array}$ \\
$\begin{array}{c}\text { Controls } \\
(\mathrm{n}=10)\end{array}$ & $19.0 \pm 2.0$ & \\
\hline
\end{tabular}

\section{Impotent Patients (Table 2 and 3)}

Basal testosterone, LH and FSH levels in impotent and non-impotent diabetics showed no significant difference from control subjects. The percentage binding of testosterone was the same in all patient groups. The FSH response to LHRH was greater in the impotent than in the non-impotent patients $(\mathrm{P}<0.05)$ but there was no difference in the LH responses.

\section{Discussion}

As far as the authors are aware, assessment of the pituitary responsiveness to TRH/LHRH stimulation in diabetic patients, as part of an overall assessment of pituitary function, has not been previously reported. Because of conflicting results in the literature, we surmised that minor alterations in pituitary function might not be consistently shown by the usual standard tests. For this reason we gave both a small and a standard dose of the releasing hormones to see if minor changes in pituitary function would be more readily demonstrable. The results show significant differences with the lower dose but not the standard dose.

The TSH response to TRH was greater in patients on oral agents than in the insulin group $(\mathrm{P}<0.01)$ after the low dose of TRH, suggesting a minor difference in responsiveness between the two groups (Table 2). The insulin and the control groups were not different at any point of the test. Raised TSH levels in diabetic patients have been reported by Hunton et al. [12] who attributed this to a goitrogenic effect of the sulphonylurea drugs. On the other hand, Kaufman et al. [13] produced convincing evidence implicating autoimmune factors in patients treated with oral agents. All our patients were clinically euthyroid and had normal levels of $T_{4}$ and $T_{3}$ (Table 1).

Increased prolactin responses concordant with those of TSH are commonly observed in primary hypothyroid states [21]. Despite the increased TSH response to small doses of TRH in the tablet group, the prolactin response was significantly lower than in the insulin-dependent group $(\mathrm{P}<0.02)$. This anomalous dissociation between the TSH and prolactin responses has been found in other conditions [22, 23].

Most of the diabetic patients studied showed a definite GH response to TRH/LHRH while none of the control subjects showed any response. It is clear from Fig. 2 that the changes in plasma GH levels are unrelated to changes in blood glucose levels. TRHmediated GH response has been reported in other pathological conditions, e. g. chronic renal failure [24], acromegaly [25], anorexia nervosa [26], and depression [27] while an LHRH-mediated response has been observed in acromegaly [28]. This abnormal response of $\mathrm{GH}$ indicates, we believe, a disorder in hypothalamic pituitary function in diabetics. It is interesting that a greater response was observed in the insulin-dependent patients who have greater impairment of carbohydrate metabolism. The absence of any response in the controls excludes a nonspecific effect of stress. Our results are consistent with the findings of others that $\mathrm{GH}$ release is facilitated in diabetics. This may explain why GH has been frequently, but inconsistently implicated as a cause of many diabetic complications.

Further evidence of hypothalamic pituitary dysfunction is shown by the reduced $\mathrm{LH}$ response in both insulin $(\mathrm{P}<0.01)$ and oral agents $(\mathrm{P}<0.01)$ groups following the smaller dose of LHRH.

Wright et al. [11] and Ellenberg [5] have found normal plasma testosterone levels in insulin-treated patients. This has been confirmed by us. However, we observed significantly $(\mathrm{P}<0.01)$ lower plasma testosterone levels in the group on oral agents. With two exceptions, the patients treated with oral agents had mature-onset diabetes, and it is possible that the observed low testosterone level was a reflection of basic differences between the mature-onset and juvenile-onset diabetes, perhaps due to autoimmune mechanisms. Against this, is the finding of normal testosterone levels in the group of mature-onset diabetics on dietary control alone. It is unlikely that this observation is due to differences in the mean age of the two groups $(50.5 \pm 3.5$ and $53.6 \pm 2.4$ years for the insulin-treated and oral agent-treated groups respectively) as there is no correlation between age and plasma testosterone levels. Moreover, the insulin-treated impotent and non-impotent diabetics had similar mean plasma testosterone levels (Table 3) despite a big difference in the mean age of the two groups $(55.8 \pm 5.0$ and $41.7 \pm 8.0$ years respectively). A drug effect on the level of sex hormone binding globulin (SHBG) is excluded by our finding of similar percentage binding of testosterone in the two groups. Any interference with the testosterone 
assay method has also been excluded by in-vitro experiments. The possibility remains that the sulphonylureas may have a direct inhibitory action on testosterone production by the testis, through interference with intracellular enzymes. That drugs may act in this way is well documented [29]. On the other hand, the subnormal LH response to LHRH suggests an associated defect at the pituitary level which is even more significant than the figures suggest, since an increased LH response would be expected in the presence of a low testosterone level.

We observed an increased response of FSH in impotent when compared with non-impotent diabetics, in contrast to earlier findings $[9,11]$. This would suggest the possibility of some testicular dysfunction.

\section{References}

1. Rundles, R. W.: Diabetic neuropathy. Medicine (Baltimore) 24, 111-160 (1945)

2. Rubin, A., Babbott, D.: Impotence and diabetes mellitus, J.A.M.A. 168, 498-500 (1958)

3. Faerman, I., Vilar, O., Rivarola, M. A., Rosner, J. J., Jadzinsky, M. N., Fox, D., Lloret, A. P., Bernstein-Hahn, L., Saraceni, D.: Impotence and diabetes: Studies of androgenic function in diabetic impotent men. Diabetes 21, 23-30 (1972)

4. Kolodny, R. C., Kahn, C. B., Goldstein, H. H., Barnett, D. M.: Sexual dysfunction in diabetic men. Diabetes 23, 306-309 (1974)

5. Ellenberg, M.: Impotence in diabetes: The neurologic factor. Ann. Intern. Med. 72, 213-219 (1971)

6. Cooper, A. J.: Diagnosis and management of "endocrine impotence". Br. Med. J. 1972 II, 34-36

7. Kent, J.R.: Gonadal function in impotent diabetic males. Diabetes 15, 537 (1966)

8. Schoffling, K., Federlin, K., Ditschuneit, H., Pfeisser, E. S.: Disorders of sexual function in male diabetics. Diabetes 12, 519-527 (1963)

9. Rastogi, G. K., Chakraborti, J., Sinha, M. K.: Serum gonadotrophin (LH and FSH) and their response to synthetic LHRH in diabetic men with and without impotence. Horm. Metab. Res. 6, 335-336 (1974)

10. Distiller, L. A., Sagel, J., Morley, J.E., Joffe, B. I., Seftel, H. C.: Pituitary responsiveness to luteinizing hormone-releasing hormone in insulin-dependent diabetes mellitus. Diabetes 24, 378-380 (1975)

11. Wright, A. D., London, D. R., Holder, G., Williams, J. W., Rudd, B. J.: Luteinizing release hormone tests in impotent diabetic males. Diabetes 25, 975-977 (1976)

12. Hunton, R. B., Wells, M. V., Skipper, E. W.: Hypothyroidism in diabetics treated with sulphonylurea. Lancet $1965 \mathrm{I}$, $449-451$

13. Kaufmann, B. M., Tunbridge, W. M. G., Harsoulis, P., Kuku, S. F., Lowy, C., Fraser, T. R.: The prevalence of raised TSH levels among clinically euthyroid diabetics. Abstracts of the autumn meeting of the British Diabetic Association, Medical and Scientific Section 1975

14. Hansen, A.P.: Serum growth hormone patterns in female juvenile diabetics. J. Clin. Endocrinol. Metab. 36, 638-646 (1973)

15. Johansen, K., Hansen, A. P.: Diurnal serum growth hormone levels in poorly- and well-controlled diabetics. Diabetes $\mathbf{2 0}$, 239-45 (1971)

16. Wood, P. J., Smith, J., Marks, V.: Notes on the radioimmunoassay of human thyrotrophin. Ann. Clin. Biochem. 12, 196-199 (1975)

17. Sinha, Y.N., Selby, F. W., Lewis, U. J., Vanderlaan, W. P.: Homologous radioimmunoassay for prolactin. J. Clin. Endocrinol. Metab. 36, 509-516 (1973)

18. Wood, P. J., Shahwan, M. M., Marks, V.: Radioimmunoassay of plasma prolactin. Lancet 1975 II, 1040

19. Wilde, C. E., Orr, A. H., Bagshawe, K. D.: A radioimmunoassay for human chorionic gonadotrophin. Nature 205, 191-193 (1965)

20. Rosenfield, R. L.: Plasma testosterone binding globulin and indexes of the concentration of unbound plasma androgens in normal and hirsute subjects. J. Clin. Endocrinol. Metab. 32, 717-728 (1971)

21. Rappaport, B., Refetoff, S., Fang, V. S., Friesen, H. G.: Suppression of serum thyrotropin (TSH) by L. dopa in chronic hypothyroidism: Interrelationships in the regulation of TSH and prolactin secretion. J. Clin. Endocrinol. Metab. 36, 256-262 (1973)

22. L'Hermite, M., Robyn, C., Golstein, J., Rothenbuchner G., Birk, J., Loos, U., Bonnyns, M., Vanhaelst, L.: Prolactin and thyrotropin in thyroid disease: lack of evidence for a physiological role of thyrotropin-releasing hormone in the regulation of prolactin secretion. Horm. Metab. Res. 6, 190-195 (1974)

23. Kannan, C., Akbar, M., Begum, F., Dwarakanathan, A., Burke, G.: Dissociation between TSH and prolactin dynamics in treated thyrotoxicosis. Clin. Endocrinol. (Oxf.) 5, 331-340 (1976)

24. Czernichow, P., Dauzet, M. C., Broyer, M., Rappaport, R.: Abnormal TSH, PRL and GH response to TSH releasing factor in chronic renal failure. J. Clin. Endocrinol. Metab. 43, 630-637 (1976)

25. Irie, M., Tsushima, T.: Increase of serum growth hormone concentration following thyrotropin-releasing hormone injection in patients with acromegaly or gigantism. J. Clin. Endocrinol. Metab. 35, 97-100 (1972)

26. Maeda, K., Kato, Y., Yamaguchi, N., Chihara, K., Ohgo, S., Iwasaki, Y., Yashimoto, Y., Moridera, K., Kuromaru, S., Imura, H.: Growth hormone release following thyrotropin releasing hormone injection with patients with anorexia nervosa. Acta Endocrinol. (Kbh.) 81, 1-8 (1976)

27. Maeda, K., Kato, Y., Ohgo, S., Chihara, K., Yoshimoto, Y., Yamaguchi, N., Kuromaru, S., Imura, H.: Growth hormone and prolactin release after injection of thyrotropin-releasing hormone in patients with depression. J. Clin. Endocrinol. Metab. 40, 501-505 (1975)

28. Faglia, G., Beck-Peccoz, P., Travaglini, P., Paracchi, A., Spada, A., Lewin, A.: Elevation in plasma growth hormone concentration after luteinizing hormone-releasing hormone (LRH) in patients with active acromegaly. J. Clin. Endocrinol. Metab. 37, 338-340 (1973)

29. Burns, J. J., Conney, A. H.: Enzyme stimulation and inhibition in the metabolism of drugs. Proc. R. Soc. Med. (Suppl.) 58, 955-960 (1965)

Received: August 25, 1977,

and in revised form: January 30,1978

Dr. G. S. Spathis

Department of Medicine

St. Helier Hospital

Wrythe Lane

Carshalton, Surrey SM5 1AA

England 